\title{
APPLICATION OF MOLECULAR MARKERS IN LIVESTOCK IMPROVEMENT
}

\author{
A.Teneva ${ }^{1}$, M. P. Petrović ${ }^{2}$ \\ ${ }^{1}$ University of Forestry, Bulgaria \\ ${ }^{2}$ Institute for Animal Husbandry, Belgrade, Republic of Serbia \\ Corresponding author: nas15@abv.bg \\ Review paper
}

Abstract: With recent developments in DNA technologies, a large number of genetic polymorphisms at DNA sequence level has been introduced over the last decades as named DNA-based markers. The discovery of new class of DNA profiling markers has facilitated the development of marker-based gene tags, mapbased cloning of livestock important genes, variability studies, phylogenetic analysis, synteny mapping, marker-assisted selection of favourable genotypes, etc. The most commonly used DNA-based markers have advantages over the traditional phenotypic and biochemical markers since they provide data that can be analyzed objectively. In this article the main applications of molecular markers in present-day breeding strategies for livestock improvement - parentage determination, genetic distance estimation, genetic diversity, gene mapping and marker-assisted selection have been reviewed. QTLs,MAS

Key words: livestock, DNA markers, genetic diversity, genome maps,

\section{Introduction}

The progress in development of molecular markers suggests their potential use for genetic improvement in livestock species. The reason for this is among other things, the desire to find an effective way to overcome the limitations that incorporates traditional techniques of selection (Petrovic et al., 1997; Petrovic, 2000). The markers are the genetic basis for assessing of the observed phenotypic variability.Genetic markers are distinguished on three principle classes: based on visually evaluated traits (morphological and productive traits), based on gene product (biochemical markers), and founded on DNA analysis (molecular markers). The idea of using the genetic markers came forward very early in the scientific studies (Sax, 1923) but the development of electrophoretic separation of isozymes (Markert and Moller, 1959) and molecular markers (Botstein et al., 1980; 
Nakamura et al., 1987; Williams et al., 1990; Vos et al., 1995; Caetano-Anolles and Gresshoff, 1997; Jaccoud et al., 2001) made better the comprehensions in biological based sciences. Molecular markers are specific fragments of DNA that can be identified within the whole genome and transmitted by the Mendel's laws of inheritance in the generations. They are not considered as normal genes and as a rule do not have phenotypic effect. The existence of different molecular techniques require attentive consideration in choosing the relevant marker. This review article examine the most widely used molecular markers for genetic diversity studies, genetic mapping, marker-trait association studies, and marker assisted selection programs.

The modern developments in molecular biological research connected with livestock breeding include:

1. Assignment of the entire genome sequence of the most important livestock species.

2. Development of technology to measure DNA polymorphisms at loci widespread in the genome (microsatellites and SNPs)

3. Development of microarray technology to measure gene transcription.

\section{Evaluation of genetic diversity}

Genetic diversity among organisms is a result of variations in DNA sequences. Genetic variation is essential, and each individual, with the exception of monozygotic twins, possesses a nonpareil DNA sequence. DNA variations are mutations resulting from substitution of single nucleotides (SNPs), insertion or deletion of DNA fragments of various lengths, or duplication or inversion of DNA fragments. DNA variations are specified as "neutral" when they cause no change in phenotypic traits, and thereby are not subjected to positive, negative, or balancing selection and in the opposite they are referred to as "functional".

The genetic diversity found in domestic breeds allows breeders to develop new characteristics in response to changes in environment, diseases or market conditions. Furthermore, losing genetic diversity represents a loss to the history of civilization. A considerable number of genetic diversity studies for several livestock species have been carried out during recent years by research teams from all over the world (Ciampolini et al., 1995;Martin-Burriel et al.,1998;Peelman et al., 1998; Mommens et al., 1998. Čitek, Řehout. 2001;Canon et al., 2001;Cervini et al., 2006; Mommens et al., 1999, Rendo et al., 2004; M. Zho et al., 2005; Teneva et al.,2005;Czernekova et al., 2006; Teneva et al., 2007; Guimeraes, 2007; Cinkulov et al., 2008; Loukou et al., 2009, Teneva et al.,2009).

Currently, microsatellites are the most popular markers in livestock genetic characterization studies (Simianer, 2007). To define species-specific standards, the International Society for Animal Genetics (ISAG) formed a FAO/ISAG advisory 
group on animal genetic diversity which name was changed at the ISAG-meeting (2004) to ISAG/FAO advisory group on animal genetic diversity'. This group developed guidelines for cattle, sheep, pig, and chicken, published in the Secondary Guidelines for Development of National Animal Genetic Resources Management Plans: Measurement of Domestic Animal Diversity (MoDAD): Recommended Microsatellite Markers. In these recommendations, which were widely spread in the scientific community, 30 microsatellite markers for cattle, 25 for chicken, 27 for sheep and 27 for pigs, respectively, were listed (http://dad.fao.org./) (Simianer, 2007). After Simianer (2007) the microsatellites are the primary marker class of choice, but in most studies additional marker types like AFLPs are also used. The single nucleotide polymorphisms (SNPs) would be a more appropriate choice. As suggested by Werner et al. (2004) SNP markers will be a superior and more cost-efficient technical approach in the future.

Peter et al. (2007) analyzed the population structure and the genetic diversity of 57 European sheep breeds from 15 European countries and differentiate the following groups of sheep: Mid-eastern fat tailed sheep, South eastern European sheep and North western/Western European sheep.

Markers such as microsatellites and AFLP were not only used to evaluate the genetic diversity, but also to decide on conservation priorities for cattle breeds. The European Cattle Diversity Consortium (2006) investigated the genetic distances between 69 European cattle breeds to indicate conservation priorities. The use of markers derived from genes within diversity studies can also lead to a deeper knowledge about the domestication and development of livestock species and breeds. For example, the analysis of the geographic distribution of casein haplotypes in cattle gave information about the consequences of the domestication geographically differentiated natural or artificial selection (Jann et al., 2004; Beja Peirera et al., 2006; Taberlet et al. 2007). As in cattle and sheep, a European project dealing with genetic diversity in pig breeds was established in recent years (Pig biodiversity Project II). The results of microsatellite typing present strong support for clustering of European pig breeds (SanCristobal et al., 2006).

\section{Genotyping}

AFLP and microsatellites are the ideal molecular approaches for population genetics and genome typing except (Luikart et al., 2003). In the past years AFLP approach is more frequently used to identify markers associated with traits under selection in non-model plant and vertebrate species (Young et al., 1999). In some species, only a limited number of microsatellite markers may have been produced. In this case, the usual alternative is to use a fingerprinting technique, such as RAPD or AFLP. Although RAPD is technically less demanding than AFLP, the latter technique will produce more reproducible data, which will be easier to share 
between laboratories. The main interest of both techniques, is to use the same reagents, whatever the species studied. However, RAPD and AFLP produce biallelic dominant types of markers and therefore, to achieve the same resolution power as with microsatellites or even SNPs, a higher number of markers will have to be studied.

The microsatellites are the markers of choice for genotyping, because they are highly informative, distributed in the whole genome and because it is possible to amplify different regions simultaneously (Buchanan et al., 1994; MacHugh et al.,1997; Krüger, et al., 2002).

At present, SNPs (Single Nucleotide Polimorphisms) represent the most innovative molecular markers in genotyping studies. On the other hand, recent advances in high-throughput DNA sequencing, computer software and bioinformatics have facilitated and improved the identification of SNP (Single Nucleotide Polymorphism). SNPs represent one of the more interesting approach in animal identification because they are abundant in the genome, genetically stable and amenable to high-throughput automated analysis (Syvänen 2001). SNPs have been already employed in animal identification and paternity analysis in American and European beef and dairy breeds (Heaton et al. 2002; Werner et al. 2004) and in analysis on genetic distance (Werner et al., 2002).

\section{Genome mapping}

Advances in molecular biology techniques and the rapid development of DNA markers facilitated the development of comprehensive linkage maps of livestock species cattles, sheeps, goats, pigs, chicken (Ellegren et al., 1994; Rohrer et al., 1996 and 1998).

Genetic maps are constructed on the basis of two classes of molecular markers: Type I markers that represent the evolutionary conserved coding sequences (classical RFLPs), are useful in comparative mapping strategies where polymorphism is not necessary. The type II markers (SSR and STMS) have higher polymorphism information content (PIC) than conventional RFLPs, can be generated very easily and rapidly and are more useful to produce gene maps.

The opening stage of endeavour at the construction of a genetic map for the chicken genome dates far back as 1936 (Fillion, 1998). Since then were established and corresponding maps were constructed, which resulted in a consensus map for the chicken genome (Bumstead and Palyga, 1992; Crittenden et al., 1993; Cheng et al., 1998; Groenen et al., 2000). The first reported map in livestock was for chicken in 1992, which was quickly followed by the publication of maps for cattle, pigs and sheep. Since then, the search for useful markers has continued and further species have been targeted, including goat, horse, rabbit and turkey (Guimaraes, 2007). The current status of the genomic maps for cattle, sheep, pig and chicken 
are mapped over 1500 loci in cattle, 370 in sheep, 260 in goat, 640 in pig, 580 in chicken (Haley and de Koning, 2006). Information obtained through the sequencing of the entire genome, achieved for chickens and cattle (Elsik et al.2009; Liu et al.2009; Zimin et al.2009), integrated with SNP technology, will speed up the search for genes. One of the big surprises from the research was the discovery that cattle have far more in common genetically with humans than mice or rats have with humans. This suggests that cattle may make better subjects for studying human health. Scientists estimate that the cattle genome contains approximately 22 000 genes, 80 per cent of which are shared with human beings. In addition to helping medical researchers gain insight into the human genome and thereby develop improved ways of treating and preventing disease, the bovine genome sequence will serve as a tool for agricultural researchers striving to improve health and disease management of cattle and enhance the nutritional value of beef and dairy products. Like humans and other mammals, the chromosomes of cattle contain segmental duplications, which are large, almost identical copes of DNA present in at least two locations in a genome.

Genetic maps of livestock genomes have been applied in several linkage studies to map loci and genes that underlie genetic variance of economically important traits (Jungerus et al.,2003,2004; Jungerius,2004; Guimaraes, 2007).

\section{Quantitative Trait Loci}

Following Sax (1923), many methods have been developed in the literature for detecting quantitative trait loci (QTL) using marker information.

Quantitative genetics is based on an assumption that performance of livestock results from effects of multiple genes at multiple loci, all of which have small, additive effects on performance. This is known as polygenic inheritance. Production traits show a continuous distribution of phenotypic values rather than discrete phenotypic values and are therefore referred to as quantitative traits. They are controlled by multiple genes and may be influenced by several environmental factors. Genes influencing quantitative trait can be identified through two different strategies: the candidate gene approach and the whole genome scan approach.

The candidate gene approach applies previous knowledge about the functions of genes to select those genes that might be involved in the trait of interest. The selected candidate genes are tested for association with the trait or phenotype. The candidate gene approach has particularly been successful for relatively simple traits with only few genes involved in different species - cattles, pigs, chicken (Kijas et al., 2001; Bradley et al., 2007; Leyva-Baca et al., 2007; Rao et al., 2007; Halabian et al.,2008).

The myostatin $(M H)$ locus which contains a series of mutations which disrupt the myostatin function, detected in several European cattle breeds causing 
muscular hypertrophy (Georges et al., 1998). Rohrer and Keele (1998), Rohrer (2000), Jungerus et al. $(2003,2004)$ reported of Identification of quantitative trait loci affecting carcass composition in swine.

In the whole genome scan approach, a large number of genetic markers RFLP, microsatellites or other similar molecular systems (Beattie, 1994) from across the genome is analysed to observe segregation of chromosomal segments through a pedigree. Many studies have demonstrated that individual loci affecting quantitative traits (QTL) can be detected via linkage to genetic markers (Beever et al., 1990; Andersson et al., 1994; Georges et al., 1995; Ashwell et al., 1997). By analyzing the co-segregation of the phenotypic trait or value with certain chromosomal segments in an experimental population, chromosomal regions harbouring genes affecting a quantitative trait can be identified and is referred to as a quantitative trait locus (QTL) (Andersson et al., 1994; Geldermann et al. 1996; Bovenhuis et al., 1997).

In several studies, different experimental crosses have been used to detect QTL regions

for fatness and meat quality traits in pigs (Andersson et al., 1994; Knott et al., 1998; Rohrer and Keele, 1998; Walling et al., 1998; Wang et al., 1998; de Koning et al., 1999; Jeon et al., 1999; Rohrer et al., 2000; Rattink et al., 2000; PérezEnciso et al., 2000; Wada et al., 2001; Bidanel et al., 2001; Malek et al., 2001; Bidanel and Rothschild, 2002).

To date, the markers used in genome scans are almost exclusively microsatellite markers, which occur once every 30 to $46 \mathrm{~kb}$ in pigs (Winterø et al, 1992; Archibald et al., 1995). SNP markers are far more abundant with an occurrence of about 1 SNP per kb in humans (Wang et al., 1998) and about 1 SNP per 500 bp in mice (Lindblad-Toh et al., 2000) and cattle (Heaton et al., 2001). Because of their abundance SNPs have high potential for detailed haplotype analysis and application in association studies. In addition, SNPs are more suitable for association studies because they are almost exclusively identical by descent because of their relatively low mutation rate.

In dairy cattle the loci responsible for milk production and protein and fat content have received considerable attention. Initially, milk yield and protein quantity were linked to chromosomes 14 and 21 by Coppieters et al. (1998) and Vaiman (1999) respectively, which led to further work and the discovery of five possible regions associated with milk and protein yield, fat and protein percentage and milk yield. Potential QTL for fat percentage and yield and protein percentage were recently reported for chromosomes 3 and 6 respectively (Ashwell et al., 2002). Conformational type traits, associated with milk yield have been found on chromosome 27 (Ashwell et al., 1998; Sonstegard et al., 2001).

As growth and disease are of economic importance for poultry breeders, these traits have been emphasized in the search for QTL. Van Kaam et al. (1998) 
tested 368 markers, scanning the whole chicken genome in their search for QTL affecting body weight in the chicken and identified chromosome 1 as the most likely position. Further work on mapping QTL for growth and fatness on chickens is underway (Jacobsson et al., 2002). The HMGI-C gene has also been identified as a candidate gene for the $a d w$ locus or autosomal $d w a r f$ gene in the chicken, which is of importance in the broiler breeding stock programmes (Ruyter-Spira et al., 1998).

The searching for QTL in swine is reported in various studies (Rohrer and Keele, 1998; Wang et al., 1998).

\section{Marker assisted selection (MAS)}

Most of the traits considered in animal breeding programmes are quantitative. They are controlled by many genes as well as are influenced by environmental factors. The underlying genes have small effects on the phenotype observed. In conventional breeding programmes, selection is carried out based on phenotypic traits. There is no knowledge which genes are being selected. The concept of marker assisted selection (MAS), utilizing the information of polymorphic loci as an aid to selection, was introduced as early as in 1900s (Luo et al.1997). With the advent of DNA-based genetic markers in the late 1970s, and their subsequent use to detect associations with traits of interest, thus allowing MAS to become a reality.

MAS is a form of indirect selection and their accomplishment includes two steps: identification of the marker loci that is linked to QTL of economic importance and utilization of linkage association in genetic improvement programme. The association between the markers and the QTL is dependant on the distance between the markers and bull traits, type of linkage phase, and degree of linkage disequilibrium. MAS is leading to increased rate of genetic improvement through higher selection intensity, reduction of generation interval, increase in the accuracy of prediction and selection in early age for sex-limited traits.

The DNA marker maps which contain many markers of known location, interspersed at relatively short intervals throughout the genome, constructed for a range of economically important agricultural species provides successful realization of MAS (MagHugh et al., 1994; Young, 1999). After Dekkers (2004) there are three kinds of relationship between the markers and the genes of interest:

1. The molecular marker is located within the gene of interest. This is the most favourable situation for MAS which is named gene-assisted selection (GAS).

2. The marker is in linkage disequilibrium (LD) with target trait throughout the whole population. Selection using these markers is called LD-MAS. 
3. The marker is in linkage equilibrium (LE) with production trait in the whole population. Selection using these markers is refer as LE-MAS and is the most difficult situation for applying MAS.

Dekkers (2004) recently reviewed commercial applications of MAS in livestock and concluded that opportunities for the application of MAS exist, in particular for GAS and LD-MAS and, to a lesser degree, for LE-MAS because of greater implementation requirements.

Successful application of MAS in breeding programmes requires advances in the following five areas (Dekkers and Hospita, 2002; Guimaraes et al., 2007):

1. Gene mapping: identification and mapping of genes and genetic polymorphisms.

2. Marker genotyping: genotyping of large numbers of individuals for large numbers of markers at a reasonable cost for both QTL detection and routine application for MAS.

3. QTL detection: detection and estimation of associations of identified genes and genetic markers with economic traits.

4. Genetic evaluation: integration of phenotypic and genotypic data in statistical methods to estimate breeding values of individuals in a breeding population.

5. MAS: development of breeding strategies and programmes for the use of molecular genetic information in selection and mating programmes.

Most studies in cattles have considered the five economic milk production traits: milk, fat and protein production, and fat and protein concentration, although a number of studies have also considered somatic cell score (SCS), female fertility, herd life, calving traits, health traits, temperament and conformation traits. Genome scans have been completed for Holsteins from Canada (Nadesalinga et al., 2001), the Netherlands (Spelman et al., 1996; Schrooten et al., 2000), France (Bennewitz, et al., 2003; Boichard et al., 2003), Germany (Bennewitz, et al., 2003), New Zealand (Spelman et al., 1999), the United States (Georges et al., 1995; Ashwell et al., 1996, 1997, 1998, 2004; Zhang et al., 1998; Ashwell and Van Tassell, 1999; Heyen et al., 1999 Ashwell, Van Tassell and Sonstegard, 2001), Finnish Ayrshires (Viitala et al., 2003; Schulman et al., 2004), French Normande and Montbeliarde cattle (Boichard et al., 2003), Norwegian cattle in Norway (Klungland et al., 2001; Olsen et al., 2002) and Swedish Red and White (SRB) (Holmberg and Andersson- Eklund, 2004).

DNA polymorphisms that occur in and around the structural and/or regulatory sequences of a gene of physiological significance (hormone genes, milk protein genes, MHC) may directly affect gene expression and contribute to the phenotypic variations among the individuals in terms of productivity and health (disease resistance/susceptibility) in sheep, goat, chicken (Barillet, 1997; , Erceg, Petrovic and Alavantic, 1999; Hickford et al., 2004; Dekkers 2004; Barillet, 
Arranz and Carta, 2005; Olivier et al., 2005; Dominik, 2005; Davis, 2005; McRae et al., 2005; Zhou et al., 2005). Consequently, such DNA polymorphisms, occurring in the genes which already have a priori possibility to be associated or closely linked with the performance trait of importance, can be selected as markers (Georges et al, 1995; Georges et al, 1998; Haley and de Koning, 2006).

\title{
Conclusion
}

The widespread use of molecular markers offers a great potential to improve efficiency of animal breeding. Economically important traits are regulated by the combination of genes and the environment. Genetic markers are tags along the chromosome and can be used to identify the region, or loci, where the genes of interest are situated. New molecular genetic technologies will improve the use of preserved stocks and aid in assessing genetic distance and variation. Individual animals could be selected for breeding and preservation based on specific knowledge of their genotypes. As we understand more about the genome and how complex traits are controlled, and as our toolbox of techniques and methodologies grows and improves, we will increasingly be able to enhance genetic improvement of livestock as well as the management of livestock production and development of high quality products. The purpose is to use genomic information in either, functional genomics studies or in marker assisted selection to improve the efficiency in animal breeding schemes.

\section{Primena molekularnih markera u napretku stočarstva}

\author{
A.Teneva, M. P. Petrović
}

\section{Rezime}

Sa razvojem DNK tehnologija, veliki broj genetskih polimorfizama na nivou DNK sekvence su predstavljene poseldnjih godina pod nazivom DNK markeri. Otkriće novih klasa DNK markera je olakšalo razvoj marker gena, kloniranja gena od važnosti u stočarstvu i to na bazi mapa, ispitivanje varijabilnosti, filogenetske analize, mapiranja, selekcije poželjnih genotipova pomoću markera, itd. Markeri na bazi DNK koji se najčešće koriste imaju prednost $\mathrm{u}$ odnosu na tradicionalne fenotiske i biohemijske markere jer obezbeđuju podatke koji se mogu objektivno analizirati. U ovom radu su predstavljeni načini korišćenja i aplikacija molekularnih markera u postojećim odgajivačkim strategijama odn. napretku stočarstva - određivanje porekla, ocena genetske distance, genetskog diverziteta, mapiranje gena i selekcija pomoću markera. 


\section{References}

ARCHIBALD A.L., HALEY C.S., BROWN J.F., COUPERWHITE S., MCQUEEN H.A., NICHOLSON D., COPPIETERS W., VAN DE WEGHE A., STRATIL A., WINTERO A.K. (1995): The PiGMaP consortium linkage map of the pig (Sus scrofa). Mamm. Genome, 6, 3,157-75.

ANDERSSON L., HALEY C.S., ELLEGREN H., KNOTT S.A., JOHANSSON M., ANDERSSON K., ANDERSSON-EKLUND L., EDFORS-LILJA I., FREDHOLM M., HANSSON I., HAKANSSON J., LUNDSTROM K. (1994): Genetic mapping of quantitative trait loci for growth and fatness in the pig. Science 263, 1771.

ASHWELL M.S., REXROAD C.E., MILLER R.H., VANRADEN P.M. (1996): Mapping economic trait loci for somatic cell score in Holstein cattle using microsatellite markers and selective genotyping. Anim.Genet., 27, 235-242.

ASHWELL M.S., REXROAD C.E., MILLER R.H., VAN RADEN P.M., DA Y. (1997): Detection of loci affecting milk production and health traits in an elite US Holstein population using microsatellite markers. Animal Genetics, 28, 216-222.

ASHWELL M.S., DA Y., VAN RADEN P.M., REXROAD C.E., MILLER R.H. (1998): Detection of putative loci affecting conformational type traits in an elite population of United States Holsteins using microsatellite markers. J. Dairy Sci., 81, 1120-1125.

ASHWELL M.S., VAN TASSELL C.P. (1999): Detection of putative loci affecting milk, health, and type traits in a US Holstein population using 70 microsatellite markers in a genome scan. J. Dairy Sci. 82, 2497-2502.

ASHWELL M.S., VAN TASSELL C.P., SONSTEGARD T.S. (2001): A genome scan to identify quantitative trait loci affecting economically important traits in a US Holstein population. J. Dairy Sci., 84, 2535-2542.

ASHWELL M.S., HEYEN D.W., DA Y., SONSTEGARD T.S., TASSEL C.P., LEWIN H.A. (2002): Detection of QTL affecting milk production in 6 Diary Bull DANN Repository grandsire families. Proc. XXVIII Int. Conf. Anim. Gen., August 11-15, 2002. Göttingen, Germany.

BARILLET, F. (1997): Genetics of milk production. In L. Piper \& A. Ruvinsky, eds. The genetics of sheep, pp 539-564. Wallingford, UK, CABI.

BARILLET F., ARRANZ J.J., CARTA A. (2005): Mapping quantitative trait loci for milk production and genetic polymorphisms of milk proteins in dairy sheep. Genet. Sel. Evol., 37, Suppl. 1, S109-S123.

BEATTIE C.W. (1994): Livestock genome maps. Trends in Genetics 10, 334-338. BEEVER J.E., GEORGE P.D., FERNANDO R.L., STORMONT C.J., LEWIN H. A. (1990): Associations between genetic markers and growth and carcass traits in a parental halfsib familiy of Angus cattle. Journal of Animal Science, 68,337. 
BEJA-PEREIRA A., CARAMELLI D., LALUEZA-FOX C., VERNESI C., FERRAND N., CASOLI A., GOYACHE F., ROYO L.J., CONTI S., LARI M., MARTINI A., OURAGH L., MAGID A., ATASH A., ZSOLNAI A., BOSCATO P., TRIANTAPHYLIDIS C., PLOUMI K., SINEO L., MALLEGNI F., TABERLET P., ERHARDT G., SAMPIETRO L., BERTRANPETIT J., BARBUJANI G., LUIKART G., BERTORELLE G. (2006): The origin of European cattle: Evidence from modern and ancient DNA. Proc. Natl. Academy Sci. USA, 103, 8113-8118.

BENNEWITZ J., REINSCH N., GROHS C., LEVEZIEL H., MALAFOSSE A., THOMSEN H., XU N.Y., LOOFT C., KUHN C., BROCKMANN G.A., SCHWERIN M., WEIMANN C., HIENDLEDER S., ERHARDT G., MEDJUGORAC I., RUSS I., FORSTER M., BRENIG B., REINHARDT F., REENTS R., AVERDUNK G.,

BLUMEL J., BOICHARD D., KALM E. (2003): Combined analysis of data from two granddaughter designs: A simple strategy for QTL confirmation and increasing experimental power in dairy cattle. Genet. Sel. Evol., 35, 319-38.

BIDANEL J.P., MILAN D., IANNUCCELLI N., AMIGUES Y., BOSCHER M.Y., BOURGEOIS F., CARITEZ J.C., GRUAND J., LE ROY P., LAGANT H., QUINTANILLA R., RENARD C., GELLIN J., OLLIVIER L., CHEVALET C. (2001): Detection of quantitative trait loci for growth and fatness in pigs. Genet Sel Evol, 33, 3, 289-309.

BIDANEL J.P., ROTHSCHILD M. (2002): Current status of quantitative trait locus mapping in pigs. Pig News and Information, 23, 2, 39N-45N.

BRADLEY A.J. ET AL. (2007): Survey of the incidence and aetiology of mastitis on dairy farms in England and Wales. Veterinary Record, Feb 24.2.

BOICHARD D., GROHS C., BOURGEOIS F., CERQUEIRA F., FAUGERAS R., NEAU A., RUPP R., AMIGUES Y., BOSCHER M.Y., LEVEZIEL H. (2003): Detection of genes influencing economic traits in three French dairy cattle breeds. Genet. Sel. Evol., 35, 77-101.

BOTSTEIN D., WHITE R.L., SKOLNICK M., DAVIS R.W. (1980): Construction of a genetic linkage map in man using restriction fragment length polymorphisms. Am. J. Hum. Genet., 32, 314-331.

BOVENHUIS H., VAN ARENDONK J. A. M., DAVIS G., ELSEN J.-M., HALEY C.S., HILL W.G., BARET P.V., HETZEL D.J.S., NICHOLAS F.W. (1997): Detection and mapping of quantitative trait loci in farm animals. Livestock Production Science, 52, 135-144.

BUCHANAN F.C., ADAMS L.J., LITTLEJOHN R.P., MADDOX J.F., CRAWFORD A.M. (1994): Determination of evolutionary relationships among sheep breeds using microsatellites. Genomics, 22, 397-403.

BUMSTEAD N., PALYGA J. (1992): A preliminary linkage map of the chicken genome. Genomics, 13, 690-697. 
CAETANO-ANOLLES G., GRESSHOFF D.P. (1998): DNA markers. Protocols, Applications, and Overviews. Wiley-Liss.Inc. 364p.

CERVINI M., SILVA F., MORTARI N., MATHEUCCI E. (2006): Genetic variability of 10 microsatellite markers in the characterization of Brazilian Nellore cattle (Bos indicus). Genet.and Molec. Biology, 29, 3, 486-490.

CIAMPOLINI R., MOAZAMI-GOUDARZI K., VAIMAN D., DILLMAN C., MAZZANTI E., FOULLEY J., LEVEZIEL H., CIANCI D. (1995): Individual multilocus genotypes using microsatellite polymorphisms to permit the analysis of the genetic variability within and between Italian beef cattle breeds. J. Anim. Sci., 73, 3259-3268.

CINKULOV M., POPOVSKI Z., PORCU K., TANASKOVSKA B., HODZ ${ }^{\sim} \mathrm{IC}^{\prime}$ A. BYTYQI H., MEHMETI H., M. V., DJEDOVIC' R., HODA A., TRAILOVIC R., BRKA M., MARKOVIC B., VAZ IC B., VEGARA M., OLSAKER I. \& KANTANEN J.(2008): Genetic diversity and structure of the West Balkan Pramenka sheep types as revealed by microsatellite and mitochondrial DNA analysis. J. Anim. Breed. Genet., 125, 417-426

ČÍTEK J., ŘEHOUT V. (2001): Evaluation of the genetic diversity in cattle using microsatellites and protein markers. Czech J. Anim. Sci., 46, 393-400.

CHENG, H.H, BURT, D.W. \& DODGSON, J.B. (1998): Recent advances in poultry genome mapping. Proc.: Symp. Series 8 World Conf. Anim. Prod. June 28-July 4, 1998. Seoul National University, Seoul, Korea.

COPPIETERS W., RIQUET J., ARRANZ J.J., BERZI P., CAMBISANO N., GRISART B., KARIM L., MARCQ F., MOREAU L., NEZER C., SIMON P., VANMANSHOVEN P., WAGENAAR D., GEORGES M. (1998): A QTL with major effect on milk yield and composition maps to bovine chromosome 14. Mam. Genome, 9, 540-544.

CRITTENDEN L.B., PROVENCHER L., SANTANGELO L., LEVIN H.A., BRILES R W., BRILES E., DODGSON J.B. (1993): Characterization of a Red Jungle Fowl by White Leghorn backcross reference population for molecular mapping of the chicken genome. Poult. Sci., 72, 334-348.

DAVIS G.H. (2005) : Major genes affecting ovulation rate in sheep. Genet. Sel. Evol., 37, Suppl. 1, 11-23.

DEKKERS J.C.M. (2004): Commercial application of marker- and gene-assisted selection inlivestock: strategies and lessons. J. Anim. Sci., 82, 313-328.

DEKKERS J.C.M., HOSPITAL F. (2002): The use of molecular genetics in the improvement of agricultural populations. Nature Revs. Genet., 3, 22-32.

DE KONING D.J., JANSS L.L., RATTINK A.P., VAN OERS P.A., DE VRIES B.J., GROENEN M.A., VAN DER POEL J.J., DE GROOT P.N., BRASCAMP E.W., VAN ARENDONK J.A. (1999): Detection of quantitative trait loci for backfat thickness and intramuscular fat content in pigs (Sus scrofa). Genetics. 152, 4, 1679-90. 
DOMINIK S. (2005): Quantitative trait loci for internal nematode resistance in sheep: a review. Genet.Sel. Evol., 37,Suppl. 1, S83-S96.

ELSIK C.G. , TELLAM R.L., WORLEY K.C. ( 2009): The genome sequence of taurine cattle: a window to ruminant biology and evolution. The Bovine Genome Sequencing and Analysis Consortium Science,324, 522-528.

ELLEGREN H., CHOWDHARY B.P., JOHANSSON M., MARKLUND L., FREDHOLM M., GUSTAVSSON I., ANDERSSON L. (1994): A primary linkage map of the porcine genome reveals a low rate of genetic recombination. Genetics, 137, 4, 1089-1100.

ERCEG S., PETROVIC P.M, TRENKOVSKI S, ALAVANTIC D. (1999): Identification of breed specific and individual specific RAPD markers in sheep. Biotechnology in Animal Husbandry, 1-2, 11-20.

FILLION V. (1998): The chicken as a model to study microsomes in birds: review. Gen. Sel. Evol., 209-219.

GELDERMANN H., MULLER E., BEECKMANN P., KNORR C., YUE G., MOSER G. (1996): Mapping of quantativetrait loci by means of marker genes in F2 generations of Wild boar, Pietrain and Meishan pigs. J Anim Breed Genet., 113, 381-387.

GEORGES M., NIELSEN D., MACKINON M., MISHRA A., OKIMOTO R., PASQUINO A.T., SEARGEANT L.S., SORENSEN A, STEELE M.R., ZHAO X., WOMACK J.E., HOESCHELE I. (1995): Mapping quantitative trait loci controlling milk production in dairy cattle by exploiting progeny testing. Genetics, 139, 907-920.

GEORGES M., GROBET L., PONCELET D., ROYO L.J., PIROTTIN D., BROUWERS B. (1998): Positional candidate cloning of the bovine MH locus identifies an allelic series of mutations disrupting the myostatin function and causing double-muscling in cattle. Proceedings of the $6^{\text {th }}$ Word Congress on Genetics Applied to Livestock Production, Armidale, NSW., 26, 195-205.

GROENEN M.A.M., CHENG H., BUMSTEAD N., BENKEL B.F., BRILES W.E., BURKE T., BURT D.W., CRITTENDEN L.B., DODGSON J., HILLEL J., LAMONT S., PONCE DE LEON A., SOLLER M., TAKAHASHI H., VIGNAL A. (2000): A consensus map of the chicken genome. Genome Res., 137-147. GUIMARÃES E., RUANE J., SCHERF B., SONNINO A., DARGIE J. (2007): Marker-assisted selection. Current status and future perspectives in crops, livestock, forestry and fish. Food and agriculture organization of the united nations. Rome. 471p.

HALABIAN R., NASAB M.P., NASSITY M., MOSSAVI R.H., HOSSEINI S., QUANBARI S. (2008): Characterization of SNPs of bovine prolactin gene of Holstein cattle. Biotechnology, 7, 1, 118-123.

HALEY C., DE KONING D.J. (2006): Genetical genomics in livestock: potentials and pitfalls. Animal Genetics, 37, Suppl 1, 10-12. 
HEATON M.P., GROSSE W.M., KAPPES S.M., KEELE J.W., CHITKOMCKOWN C.G., CUNDIFF L.V., BRAUN A., LITTLE D.P., LAEGREID W.W. (2001): Estimation of DNA sequence diversity in bovine cytokine genes. Mammalian Genome, 12, 1, 32-7.

HEATON M.P., HARHAY G.P., BENNET G.L., STONE R.T. GROSSE W.M., ET AL. (2002): Selection and use of SNP markers for animal identification and paternity anlysis in U.S. beef cattle. Mammalian Genome, 13, 272-281.

HEYEN D.W., WELLER J.I., RON M., BAND M., BEEVER J.E., FELDMESSER E., DA Y., WIGGANS G.R., VANRADEN P.M., LEWIN H.A. (1999): A genome scan for QTL influencing milk production and health traits in dairy cattle. Physiol. Genom., 1, 165-175.

HICKFORD J.G.H., ZHOU H., SLOW S., FANG Q. (2004): Diversity of the ovine DQA2 gene. J.Anim. Sci., 82, 1553-1563.

HOLMBERG M., ANDERSSON-EKLUND L. (2004): Quantitative trait loci affecting health traits in Swedish dairy cattle. J. Dairy Sci., 87, 2653-2659.

JACCOUD D., PENG K., FEINSTEIN D., KILIAN A. (2001): Diversity arrays: a solid state technology for sequence information independent genotyping. Nucleic Acids Res., 29, 25.

JACOBSSON L.U., HEE-BOK P., SIEGEL P.B., ANDERSON L. (2002): Mapping of Quantitative Loci for growth and fatness in chickens. Proc. XXVIII Int. Conf. Anim. Gen. August 11-15, 2002. Göttingen, Germany.

JANN O.C., IBEAGHA-AWEMU E.M., OZBEYAZ C., ZARAGOZA P., WILLIAMS J.L., AJMONE-MARSAN P., LENSTRA J.A., MOAZAMIGOUDARZI K., ERHARDT G. (2004): Geographic distribution of haplotypes diversity at the bovine casein locus. Genetic Selection and Evolution, 36, 243-257.

JEON J.T., CARLBORG O., TORNSTEN A., GIUFFRA E., AMARGER V., CHARDON P., ANDERSSON-EKLUND L., ANDERSSON K., HANSSON I., LUNDSTROM K., ANDERSSON L. (1999): A paternally expressed QTL affecting skeletal and cardiac muscle mass in pigs maps to the IGF2 locus. Nat Genet., 21, 2, 157-158.

JUNGERIUS B. J. (2004): Implementation of SNPs in pig genetics: LD and QTL analysis. Thesis Wageningen University, The Netherlands, $128 \mathrm{p}$.

JUNGERIUS B.J, VEENENDAAL A., VAN OOST B.A, TE PAS M.F.W, GROENEN M.A.M. (2003): Typing single nucleotide polymorphisms using a gel based sequencer: an improved efficiency protocol and a new data analysis. Molecular Biotechnology, 25, 3, 283-287.

JUNGERIUS B.J, VANLAERE A-S, TE PAS M.F.W, BA VAN OOST, ANDERSSON L., GROENEN M.A.M. (2004): The IGF2-intron3-G3073A substitution completely explains a major imprinted QTL effect on backfat thickness in a Meishan X European white pig intercross. Genetical Research, 23, 45-53. 
KIJAS J,M,, MOLLER M,, PLASTOW G,, ANDERSSON L. (2001): A frameshift mutation in MC1R and a high frequency of somatic reversions cause black spotting in pigs. Genetics 158, 2, 779-85.

KLUNGLAND H., SABRY A., HERINGSTAD B., OLSEN H.G., GOMEZRAYA L., VAGE D.I., OLSAKER I., ODEGARD J., KLEMETSDAL G., SCHULMAN N., VILKKI J., RUANE J., AASLAND M., RONNINGEN K., LIEN S. (2001): Quantitative trait loci affecting clinical mastitis and somatic cell count in dairy cattle.

KNOTT S.A., MARKLUND L., HALEY C.S., ANDERSSON K., DAVIES W., ELLEGREN H., FREDHOLM M., HANSSON I., HOYHEIM B., LUNDSTROM K., MOLLER M., ANDERSSON L. (1998): Multiple marker mapping of quantitative trait loci in a cross between outbred wild boar and large white pigs. Genetics, 149, 2, 1069-80.

KRÜGER K., STRANZINGER G., RIEDERS S. (2002): A full genome scan panel of horse (Equus caballus) microsatellite markers applied to different equid species. Proc. XXVIII Int. Conf. on Anim. Gen. August 11-15, 2002. Göttingen, Germany. LEYVA-BACA I. ET AL. (2007): Identification of single nucleotide polymorphisms in the bovine $C C L 2, I L-8, C C R 2$ and $I L-R A$ genes and their association with health and production in Canadian Holsteins. Animal Genetics, 38, 198-202.

LINDBLAD-TOH K., WINCHESTER E., DALY M.J., WANG D.G., HIRSCHHORN J.N., LAVIOLETTE J.P., ARDLIE K., REICH D.E., ROBINSON E., SKLAR P., SHAH N., THOMAS D., FAN J.B., GINGERAS T., WARRINGTON J., PATIL N., HUDSON T.J., LANDER E.S. (2000): Large-scale discovery and genotyping of single-nucleotide polymorphisms in the mouse. Nature Genetics, 24, 4, 381-6.

LIU Y., QIN X., SONG X-Z.H., JIANG H., SHEN Y., DURBIN K.J., LIEN S., KENT M.P., SODELAND M., REN Y., ZHANG L., SODERGREN E., HAVLAK P., WORLEY K.C., WEINSTOCK G.M., GIBBS R.A. (. 2009): Bos taurus genome assembly. BMC Genomics, 10, 180.

LOUKOU N.E., YAPI-GNAORE C.V., TOURE G., Y. COULIBAL G., ROGNON X., KAYANG B. (2009): Evaluation de la diversité des poulets traditionnels de deux zones agroécologiques de Côte d'Ivoire à l'aide de marqueurs microsatellites. Journal of Animal \& Plant Sciences, 5, Issue 1, 425-436.

LUIKART G., ENGLAND P.R, TALLMON D. ET AL. (2003): The power and promise of population genomics: From genotyping to genome typing Nature Reviews Genetics, 4 12, 981-994.

LUO Z.W., THOMPSON R., WOOLLIAMS J.A. (1997): A population genetics model for marker-assisted selection. Genetics, 146, 1173-1183.

MACHUGH D.E., SHRIVER M.D., LOFTUS R.T., CUNNINGHAM P., BRADLEY D.G. (1997): Microsatellite DNA variation and the evolution, 
domestication and phylogeography of Taurine and Zebu cattle (Bos taurus and Bos indicus). Genetics, 146, 1071-1086.

MCRAE A.F., BISHOP S.C., WALLING G.A., WILSON A.D., VISSCHER P.M. (2005): Mapping of multiple quantitative trait loci for growth and carcass traits in a complex commercial sheep pedigree. Anim.Sci., 80, 135-141.

MALEK M., DEKKERS J.C, LEE H.K, BAAS T.J, ROTHSCHILD M.F. (2001): A molecular genome scan analysis to identify chromosomal regions influencing economic traits in the pig. I. Growth and body composition. Mamm. Genome, 12, 8, 630-636.

MARKERT C.L, MOLLER F. (1959): Multiple forms of enzymes: Tissue, ontogenetic and species specific patterns. Proc. Natl. Acad. Sci. USA, 45, 753-763. MARTIN-BURRIEL I., GARCIA-MURO E., ZARAGOZA P. (1999): Genetic diversity analysis of six Spanish native cattle breeds using microsatellites, Anim. Genet., 30, 177-182.

MOMMENS G, VAN ZEVEREN A., PEELMAN L. (1998): Effectiveness of bovine microsatellites in resolving paternity cases in American bison, Bison bison L. Anim. Genet., 29, 14-20.

MOMMENS G., PEELMAN F., VAN ZEVEREN A., D'IETEREN, N., WISSOCQ. (1999): Microsatellite variation between an African and five European taurine breeds results in a geographical phylogenetic tree with a bison outgroup. J. Anim. Breed. Genet., 116, 325-330.

NAKAMURA Y, LEPPERT M, O'CONNELL P, WOLFF R, HOLM T, CULVER M, MARTIN C, FUJIMOTO E, HOFF M, KUMLIN E, WHITE R. (1987): Variable number tandem repeat (VNTR) markers for human gene mapping. Science, 235,1616-1622.

NADESALINGAM J., PLANTE Y., GIBSON J.P. (2001): Detection of QTL for milk production on chromosomes 1 and 6 of Holstein cattle. Mammal. Genome, 12, 27-31.

OLIVIER J.J., CLOETE S.W.P., SCHOEMAN S.J., MULLER C.J.C. (2005): Performance testing and recording in meat and dairy goats. Small Rumin. Res., 60, 83-93.

OLSEN H.G., GOMEZ-RAYA L., VAGE D.I., OLSAKER I., KLUNGLAND H., SVENDSEN M., ADNOY T., SABRY A., KLEMETSDAL G., SCHULMAN N., KRAMER W., THALLER G., RONNINGEN K., LIEN S. (2002): A genome scan for quantitative trait loci affecting milk production in Norwegian dairy cattle. J. Dairy Sci., 85, 3124-3130.

PEELMAN L.J., MORTIAUX F., VAN ZEVEREN A., DANSERCOER A., MOMMENS G., COOPMAN F., BOUQUET Y., BURNY A., RENAVILLE R., PORTELLE D. (1998): Evaluation of the genetic variability of 23 bovine microsatellite markers in four Belgian cattle breeds. Animal Genetics, 29, 161-167. 
PETROVIC P.M., ZUJOVIC M., NEGOVANOVIC D., VLAHOVIC M., MEKIC C., ALAVANTIC D. (1997): Status and prospects of sheep breeding improvenment. Biotechnology in Animal Husbandry, 3-4, 83-87.

PETROVIC P.M (2000): Genetic and improvement of sheep. Scientific Book, Belgrade, $365 \mathrm{p}$.

PEREZ-ENCISO M., CLOP A., NOGUERA J.L, OVILO C., COLL A., FOLCH J.M, BABOT D., ESTANY J., OLIVER M.A, DIAZ I., SANCHEZ A. (2000): A QTL on pig chromosome 4 affects fatty acid metabolism: evidence from an Iberian by Landrace intercross. J Anim Sci., 78, 10, 2525-2531.

PETER C., BRUFORD M., PEREZ T., DALAMITRA S., HEWITT G., ERHARDT G., AND THE ECONOGEN CONSORTIUM. (2007): Genetic diversity and subdivision of 57 European and Middle-Eastern sheep breeds. Anim. Genet., 38, 37-44.

RAO Y., SHEN X., XIA M., LUO C., NIE Q., ZHANG D. AND ZHANG X. (2007): SNP mapping of QTL affecting growth and fatness on chicken GGA1. Genetics Selection Evolution, 39, 569-582

RATTINK A.P, DE KONING D.J, FAIVRE M., HARLIZIUS B., VAN ARENDONK J.A, GROENEN M.A. (2000): Fine mapping and imprinting analysis for fatness trait QTLs in pigs. Mamm Genome, 11, 8, 656-661.

RENDO F., IRIONDO M., JUGO B., AGUIRRE A., MAZÓN L.I, VICARIO A., GÓMEZ M, ESTONBA A. (2004): Analysis of the genetic structure of endangered bovine breeds from the Western Pyrenees using DNA microsatellite markers. Biochem Genet., 42, 99-108.

ROHRER G.A. (2000): Identification of quantitative trait loci affecting birth characters and accumulation of backfat and weight in a Meishan-White Composite resource population. J Anim Sci., 78, 10, 2547-2553.

ROHRER G.A, KEELE J.W. (1998): Identification of quantitative trait loci affecting carcass composition in swine: I. Fat deposition traits. J Anim Sci., 76, 9, 2247-2254.

ROHRER G.A, ALEXANDER L.J, HU Z., SMITH T.P, KEELE J.W, BEATTIE C.W. (1996): A comprehensive map of the porcine genome. Genome Res., 6, 5, 371-391.

SANCRISTOBAL M., CHEVALET C., HALEY C.S., JOOSTEN R., RATTINK A.P., HARLIZIUS B., GROENEN M.A.,AMIGUES Y., BOSCHER M.Y., RUSSELL G., LAW A., DAVOLI R., RUSSO V., DESAUTES C., ALDERSON L., FIMLAND E., BAGGA M., DELGADO J.V., VEGA-PLA J.L., MARTINEZ A.M., RAMOS M., GLODEK P., MEYER J.N., GANDINI G.C., MATASSINO D., PLASTOW G.S., SIGGENS K.W., LAVAL G., ARCHIBALD A.L., MILAN D., HAMMOND K., CARDELLINO R. (2006): Genetic diversity within and between European pig breeds using microsatellite markers. Animal Genetics, 37, 189-198. 
SAX K. (1923):The association of sizes differences with seed coat pattern and pigmentation in Phaseolus vulgarus. Genetics, 8, 552-560.

SCHULMAN N.F., VIITALA S.M., DE KONING D.J., VIRTA J., MAKITANILA A., VILKKI J.H. (2004): Quantitative trait loci for health traits in Finnish Ayrshire cattle. J. Dairy Sci., 87, 443-449.

SCHROOTEN C., BOVENHUIS H., COPPIETERS W., VAN ARENDONK, J.A.M. (2000): Whole genome scan to detect quantitative trait loci for conformation and functional traits in dairy cattle. J. Dairy Sci., 83, 795-806.

SONSTEGARD T.S., VAN TASSEL C.P., ASHWELL M.S. (2001): Dairy cattle genomics: Tools to accelerate genetic improvement? J. Anim. Sci., 79, E. Suppl., 307-315.

SPELMAN R.J., COPPIETERS W., KARIM L., VAN ARENDONK J.A.M., BOVENHUIS H. (1996): Quantitative trait loci analysis for five milk production traits on chromosome six in the Dutch Holstein-Friesian population. Genetics, 144, 1799-1808.

SYVÄNEN A.C. (2001): Accessing genetic variation: genotyping single nucleotide polymorphisms. Nature Reviews-Genetics. 2, 930-942

TABERLET P., VALENTINI A., REZAEI H.R., NADERI S., POMPANON F., NEGRINI R., AJMONE-MARSAN P. (2007): Are cattle, sheep, and goats endangered species? Molecular Ecology, 12-24.

TENEVA A., TODOROVSKA E., TYUFEKCHIEV N., KOZELOV L., ATANASSOV A., FOTEVA S., RALCHEVA S., ZLATAREV S. (2005): Molecular characterization of Bulgarian livestock genetic resources. I. Genetic diversity in Bulgarian Grey cattle as revealed by microsatellite markers. Biotechnology in Animal Husbandry, 21, 5-6, 35-41.

TENEVA A., E. TODOROVSKA, N. TYUFEKCHIEV, A. STELLA , P. BOETTCHER, I. DIMITROVA(2007):Molecular characterization of Bulgarian livestock genetic resources. II. Microsatellite variation within and among Bulgarian cattle breeds. Biotechnology in Animal Husbandry, 23, 5-6, 227-242.

TENEVA A., DIMITROVA I., GEORGIEV G., POLIHRONOVA L., IVANOVA K. (2009): Molecular characterization of Bulgarian livestock genetic resources and their optimized utilization for animal production. FAO/IAEA International Symposium on Sustainable Improvement of animal Production and Health, 8-11 June 2009, Vienna, Austria, Synopses -126-127

TENEVA A. (2009): Molecular markers in animal genome analysis. 9-th International Symposium Modern Trends in Livestock Production, Belgrade, Biotechnology in Animal Husbandry, 25, 5-6, 1267-1285.

TENEVA A., TODOROVSKA E, TYUFEKCHIEV N., STELLA A, BOETTCHER P., DIMITROVA I. (2007): Molecular characterization of Bulgarian livestock genetic resources. II. Microsatellite variation within and among Bulgarian local cattle breeds. Biotechnology in Animal Husbandry, 23, 5-6, 227-242. 
WADA Y., AKITA T., AWATA T., FURUKAWA T., SUGAI N., INAGE Y., ISHII K., ITO Y., KOBAYASHI E., KUSUMOTO H., MATSUMOTO T., MIKAWA S., MIYAKE M., MURASE A., SHIMANUKI S., SUGIYAMA T., UCHIDA Y., YANAI S., YASUE H. (2000): Quantitative trait loci (QTL) analysis in a Meishan x Gottingen cross population.Anim Genet., 31, 6, 376-384.

WALLING G.A, ARCHIBALD A.L, CATTERMOLE J.A, DOWNING A.C, FINLAYSON H.A, NICHOLSON D., VISSCHER P.M, WALKER C.A, HALEY C.S. (1998): Mapping of quantitative trait loci on porcine chromosome 4. Anim Genet., 29, 6, 415-424.

VAIMAN D. (1999): The molecular genetics of cattle. In: The Genetics of Cattle. Eds. Fries, R. \& Ruvinsky, A., CABI Publishing, CAB International, UK.

VAN KAAM J.B.C.H.M., VAN ARENDONK J.A.M., GROENEN M.A.M., BOVENHUIS H., VEREIJKEN A.L.J., CROOIJMANS R.P.M.A., VAN DER POEL J.J., VEENENDAAL A. (1998): Whole genome scan for quantitative trait loci affecting body weight in chickens using a three generation design. Livest. Prod. Sci., 54, 133-150.

VIITALA S.M., SCHULMAN N.F., DE KONING D.J., ELO K., KINOS R., VIRTA A., VIRTA J., MAKI-TANILA A., VILKKI H.J. (2003): Quantitative trait loci affecting milk production traits in Finnish Ayrshire dairy cattle. J. Dairy Sci., 86, 1828-1836.

VOS P., HOGERS R., BLEEKER M., REIJANS M., VAN DE LEE T., HORNES M.,FRIJTERS A., POT J., PELEMAN J., KUIPER M., ZABEAU M. (1995): AFLP: a new technique for DNA fingerprinting. Nucleic Acids Res., 23, 44074414.

WANG L., YU T.P, TUGGLE C.K, LIU H.C, ROTHSCHILD M.F. (1998): A directed search for quantitative trait loci on chromosomes 4 and 7 in pigs. J Anim Sci., 76, 10, 2560-2567.

WERNER F.A.O., DURSTEWITZ G., THALLER G., BARKEMEYER H., IRPS U., ET AL. (2002): Standardized presentation of SNP genotypes for paternity testing, individual identification and genetic distance analysis. I.S.A.G.

WERNER F.A.O., DURTSEWITZ G., HABERMANN F.A., THALLER G., KRÄMER W. (2004): Detection and characterization of SNPs useful for identity control and parantage testing in major European dairy breeds. Animal Genetics, 35, 44-49.

WILLIAMS J.G.K, KUBLELIK A.R, LIVAK KJ, RAFALSKI J.A, TINGEY S.V. (1990):DNA polymorphism's amplified by arbitrary primers are useful as genetic markers. Nucleic Acids Res., 18, 6531-6535.

WINTERØ A.K, FREDHOLM M., THOMSEN P.D. (1992): Variable (dGdT)n.(dC-dA)n sequences in the porcine genome. Genomics, 12, 2, 281-288.

ZHANG Q., BOICHARD D., HOESCHELE I., ERNST C., EGGEN A., MURKVE B., PFISTER-GENSKOW M., WITTE L.A., GRIGNOLA F.E., 
UIMARI P., THALLER G., BISHOP M.D. (1998): Mapping quantitative trait loci for milk production and health of dairy cattle in a large outbred pedigree. Genetics, 149, 1959-1973.

ZHO LI., HAIGUOJIN Q., SHALIGUO I., UHOUWU Y. (2005): Genetic diversity analysis of five cattle breeds native to China using microsatellites. Journal of Genetics, 84, 1, 77-80.

ZHOU H., MITCHELL A.D., MCMURTRY J.P., ASHWELL C.M., LAMONT S.J. (2005): Insulin-like growth factor-1 gene polymorphism associations with growth, body composition, skeleton integrity, and metabolic traits in chickens. Poult. Sci., 84, 212-219.

Received 22 March 2010; accepted for publication 22 June 2010 